\title{
NUMERALS AND PHONETIC COMPLEMENTS IN THE KOHAU RONGORONGO SCRIPT OF EASTER ISLAND
}

\author{
ALBERT DAVLETSHIN \\ Russian State University for the Humanities \\ Institute for Oriental and Classical Studies, Moscow
}

E ho'oulu ana i ke kini o ke akua, ka lehu o ke akua, ka mano o ke akua. Invoke we now the 40,000 gods, the 400,000 gods, the 4,000 gods!

Opening and closing formula of Old Hawaiian prayers (Beckwith 1940: 79)

A large number of specialist works have been dedicated to the study of indigenous Easter Island script, called kohau rongorongo. Nonetheless, it remains undeciphered, though the total length of the texts, around 11,300 glyphs, ${ }^{1}$ implies that it can be. Historiographic analysis is beyond of the scope of this article (but see Fischer 1997) and I believe that such a work should be written after some satisfactory results in decipherment have been achieved. In my opinion, the following works, in chronological order, made considerable contributions to the development of our understanding of the kohau rongorongo script: Harrison 1874, Janssen 1893, Piotrowski 1925, Ross 1940, Métraux 1940: 389-411, Kudrjavtsev 1949, Olderogge 1949, Butinov and Knorozov 1956, Barthel 1958, Guy 1982, Pozdniakov 1996, and Horley 2007 and 2009. Today various published drawings, rubbings and photographs are available for every single inscription (see for example, Piotrowski 1925; Ross 1940; Olderogge 1949; Barthel 1958; Fischer 1997; Horley 2009, 2010, 2011a). Consequently, the documentation of kohau rongorongo inscriptions may now be considered adequate even as it is being further improved by the joint efforts of scholars.

Three points are worthy of note, however. First, to date there are no efficient sign catalogues based on a thorough analysis of contexts, and moreover such a catalogue cannot be done until we look for typological parallels and have greater understanding of the script's mechanics and the social purposes for which the extant texts were conceived - that is, until we achieve a better understanding of their content. Second, bilingual texts in the strict sense of the word are unknown and artificial bilingual texts are few. By the term "artificial bilingual texts" I mean cases where either a particular structure of a text, or contexts of an inscription, permit us to compare it with either extant alphabetic texts or examples of spoken speech in a particular language and at least partially recognise its content. Put another way, artificially bilingual is a content interpretation of a text based on external data. Third, the majority of works on the script lack consistency from a typological point of view and 
from the perspective of the history of decipherment; for example, no sign types have yet been defined, no phonetic complements have been either found or searched for, no persuasive grammatical analysis of the texts has been suggested (for attempts see Fedorova 1982, Kondratov 1969) and sometimes grammatical markers are considered under-represented or totally omitted in the texts (Barthel 1958: 316; Butinov and Knorozov 1956, Fedorova 1982, Kondratov 1969, 1976). No "name-tags", i.e., culturally widespread texts denoting the ownership of inscribed objects and making reference to the objects on which they are inscribed, have been looked for (see Houston, Stuart and Taube 1989, Mathews 1979). Statistical methods, based on the idea of simple counts of signs without taking into account the contexts where they are attested, remain popular in the field (Harris 2010; Horley 2005, 2007; Kondratov 1969; Melka 2009a; Pozdniakov 1996; Pozdniakov and Pozdniakov 2007). I believe that this situation is attributable to the peculiar nature of the surviving kohau rongorongo texts; we are forced to deal with a limited number of lengthy texts written with an intricate graphic system and without word-dividers of any kind. This graphic system makes extensive use of complicated ligatures consisting of several individual signs with no clear reading order. By the term "ligatures" I mean connected writing of several independent signs without blank spaces between them. It should be noted that it is sometimes difficult and even impossible to dissect a ligature into individual signs owing to the lack of parallel passages where the signs in question are found disconnected.

\section{THEORETICAL FRAMEWORK}

The theoretical framework used in this article is the typological approach; all the known hieroglyphic scripts are recognised as logosyllabic writing systems. Hence, all known logosyllabic writing systems in the world share many traits and devices for writing speech in natural languages. Some features that are typologically infrequent and even ones unattested in the known writing systems might have a place in the script of Easter Island. However, it is rather unlikely. We can search for examples of typologically common features and devices in the rongorongo script and explain them by analogy with well understood logosyllabic scripts if the proposed analogical explanations fit the context. All the well-known logosyllabic writing systems possess at least two functional types of signs: phonetic signs (those that indicate abstract sequences of sounds) and word-signs (signs that spell a word and indicate its meaning). These systems use the former as terminal phonetic complements in order to clarify the reading of the latter, indicating and at least partially reiterating the reading of word-signs (see Gelb 1963). In the logosyllabic writing systems phonetic signs are syllabic and never alphabetical; in many 
logosyllabic scripts all the phonetic signs are of CV shape only, where C stands for a consonant and $\mathrm{V}$ for a vowel. In this article I use the traditional system of sign transliteration and follow conventions shared by Assyriologists, Mayanists and others (see Caplice 2002, Fox and Justeson 1984, Kettunen and Helmke 2010; and also Payne 2010), in which transliterated signs are printed in bold case, word-signs are given in capitals and phonetic signs in small letters. Specifically, a stylised image of the jaguar head in Mayan inscriptions has the value B'AHLAM JAGUAR and frequently, though not always, it appears accompanied by a phonetic sign ma, in which case both signs are used to spell the word b'ahlam 'jaguar'. A few examples of the word written with phonetic signs only are attested in the script: b'a-la-ma $b$ 'ahlam 'jaguar'. Semantic determinatives, that is, signs used to indicate the semantic class to which a spelled word belongs, are attested in many but not all hieroglyphic scripts. Initial phonetic complements are uncommon and even absent in many logosyllabic writing systems (see, for example, Grube 2010). Recognition of different functional types of signs and rules of their combination has been a very important achievement in decipherments. Thus, it makes sense to look for word-signs, phonetic signs and phonetic complements in the script of Easter Island. The traditional transliteration system facilitates the kind of analysis applied throughout this article.

From a technical point of view, the notion of internal data of text is crucial here; every single sign and every single text have their inherent combinatorial properties which, at least partially, can be revealed by analysing the behaviour of independent signs and their combinations, without resorting to evidence external to the analysed text (see Knorozov 1982). Combinatorial properties of an individual sign, if the data are sufficient, should allow us to understand its functional loads: for example, in showing the particular functional type the sign belongs to and to finding its complete and partial equivalencies with other signs. The inherent properties of a text, that is to say, the combinatorial properties of certain signs in a given text, are what I shall call "text structure". A retrieved text structure can be searched for comparison with external data, par excellence, traditional texts written with alphabetic characters in the Rapanui language. In the case of a successful comparison with external data, inherent properties of a text will provide us with an artificial bilingual-the most valued cornerstone in deciphering.

While describing the combinatorial properties of signs in logosyllabic scripts, the method of sign substitution has shown to be beneficial (Knorozov 1952: 116, Lounsbury 1984, Stuart 1987). The method consists of examining changes in the writing of the "presumed" same unit of script in identical contexts, where identical surroundings implicate the same meaning or, better said, the same value of the signs in question. The method has been useful 
for revealing phonetic complements and establishing equivalences between signs. The equivalences can be of two types: equivalencies between two visually different signs or two graphic variants of the same sign that possess the same reading value (allographs); and equivalencies between a sign and a sign group, when a word-sign, a combination of phonetic signs, and a combination of a word-sign and phonetic complements to the word-sign, are used to spell the same word. Patterns of substitution based on unique cases and, including some additional changes in the signs occurring both before and after the sign in question, should not be considered substitutions because they might result in erroneous interpretations. It is important to distinguish complete and incomplete substitutions; incomplete substitutions are those which show interchange between two signs not in all contexts, but only in some particular ones. If not explained by the idiosyncrasy of a scribe or a scribal school, an incomplete substitution does not imply identical, but rather similar, reading values of two signs or two sign groups.

Fortunately, the surviving kohau rongorongo texts provide us with many different testing areas for the study of substitutions. These include: (i) two lengthy parallel texts, one consisting of three examples - the Great St Petersburg Tablet, the Small St Petersburg Tablet and the Great Santiago Tablet (Kudrjavtsev 1949) and another one of two examples - the London Tablet and the Small Santiago Tablet, Recto (Butinov and Knorozov 1956), as well as (ii) several attested lists (Barthel 1958, Butinov and Knorozov 1956) (iii), recurrent sign-groups shared by various texts (Butinov and Knorozov 1956, Horley 2007, Pozdniakov 1996) (iv) and highly structured text fragments (Guy 1982).

I consider both currently available sign catalogues for the kohau rongorongo script (Barthel 1958, Pozdniakov and Pozdniakov 2007) unsatisfactory and misleading when analysing texts, even though they provide many interesting insights. Therefore I will use descriptive nicknames such as, for example, "Turtle", and ask the reader to consult the figures and discussion of graphic variation attested for a particular sign in the article. While this method of rendering signs may seem superfluous and awkward for a reader who knows the mentioned catalogues by heart, it allows me to deal with graphic designs directly and protects against overgeneralisations in graphic analysis. It is important to emphasise that the specific nickname "Turtle" does not mean that the sign should be read "turtle" or that it depicts one. Rather it simply means that the sign looks like one. However, to the extent possible, I am inclined to apply descriptive nicknames consistent with iconographic analysis of the signs in question. For the sake of clarity, I append a list of the signs discussed with their nicknames and the numbers that refer to the generally accepted system of graphic transcription (Barthel 1958). In transliterations I will use the plus 
sign $(+)$, if signs are written in ligatures, that is to say, connected, and I will use the minus sign $(-)$, if they are separated by blank space in written form. The multiplier sign (x) is used to render intersections, that is to say, parallel fragments of text attested on various tablets, as for example $\mathrm{Bv} 02 \times \mathrm{Cb} 13 \mathrm{x}$ Hv10 x Pv11, where capital letters refer to Thomas Barthel's designations of the kohau rongorongo surviving texts.

When used, Bodo Spranz' drawings (published in Barthel 1958) were compared with Steven Fischer's (1997) and with published photographs (Heyerdahl 1975; Orliac and Orliac 1995, 2008; Ramírez and Huber 2000; Van Hoorebeeck 1979) and my own photographs taken in the British Museum, London, and in the Peter the Great Museum of Anthropology and Ethnography, St Petersburg.

Finally, a remark about ligatures: I find it conceivable that many rongorongo ligatures are insignificant and might be explained by graphic reasons. For example, some signs ("Fishing Line", "Leaved Vine", etc.) when written appear attached to other signs because of their peculiar shape (Davletshin 2012: Fig. 5).

\section{RECONSIDERING THE SO-CALLED "LUNAR CALENDAR"}

In his seminal work on Easter Island script Barthel (1958: 242-47) suggested that a highly structured fragment of the text on the Mamari Tablet represents a record of an ancient Rapanui lunar calendar. This interpretation has gained wide acceptance in the literature and a number of works have been dedicated to its elaboration (Berthin and Berthin 2006, Guy 1990, Horley 2011b, Krupa 1971, Pozdniakov 2011, Wieczorek 2011). Some of them assert that it is the only secure content interpretation ever offered for kohau rongorongo texts (Melka 2009b: 111, Pozdniakov and Pozdniakov 2007: 7). In my opinion, there are only two convincing content interpretations suggested: the genealogical sequence on the Small Santiago Tablet (Butinov and Knorozov 1956) and interpretation of the text on the Santiago Staff as a name list (Yuri Knorozov pers. comm. cited in Fedorova 1997).

Let us turn to the calendric interpretation as it was set out by Barthel. At the beginning Barthel (1958: 242) asserted that in Easter Island script the moon is represented by a crescent, in the majority of cases as the waxing moon. ${ }^{2}$ This particular iconographic interpretation, as well as other interpretations of signs in Chapter 5 "The celestial bodies", was based on Metoro Tauara's readings collected by Florentin Étienne Jaussen (1893). Barthel went on to comment on a particular text passage on the Mamari, lines Ca6-9, characterised by a stereotyped sequence of signs, a sequence that is repeated eight times. The whole passage contains a total of 30 lunar signs (Fig. 1). He equates the number of lunar signs in the passage with the number of nights in the synodic 
248 Numerals and Phonetic Complements in the Kohau Rongorongo Script

A

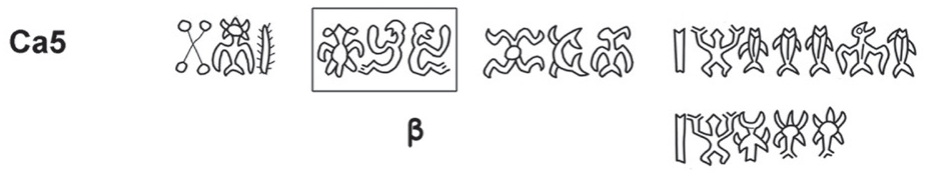

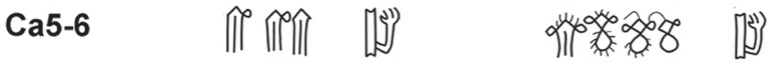

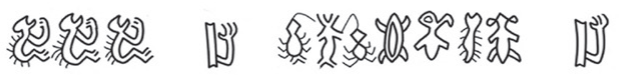

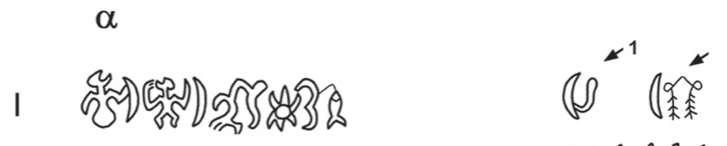

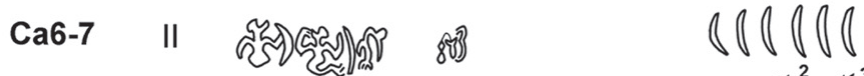

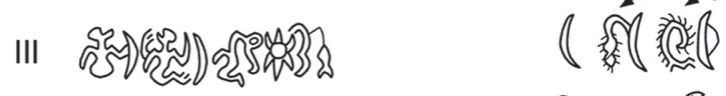

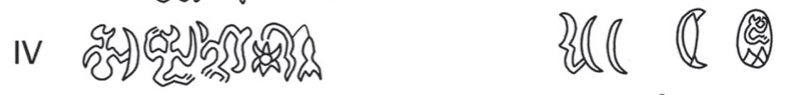

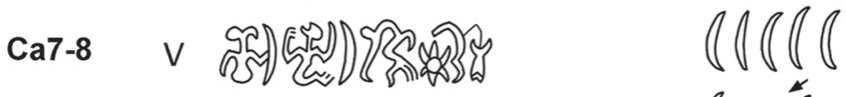

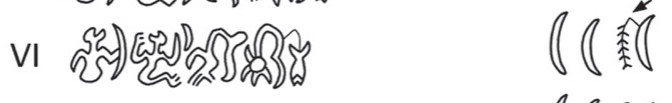

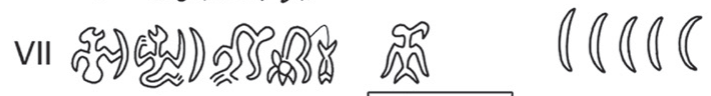

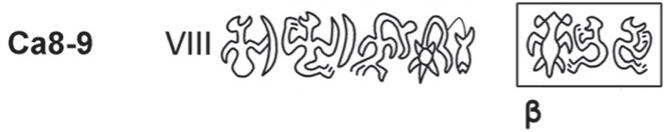

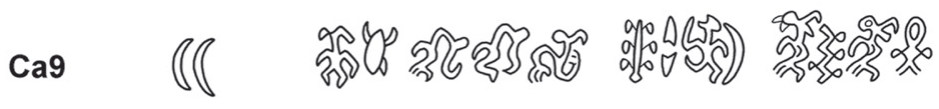

Figure 1. The so-called "calendric" passage on the Mamari Tablet, Recto. A. Structural analysis of the passage. 
B

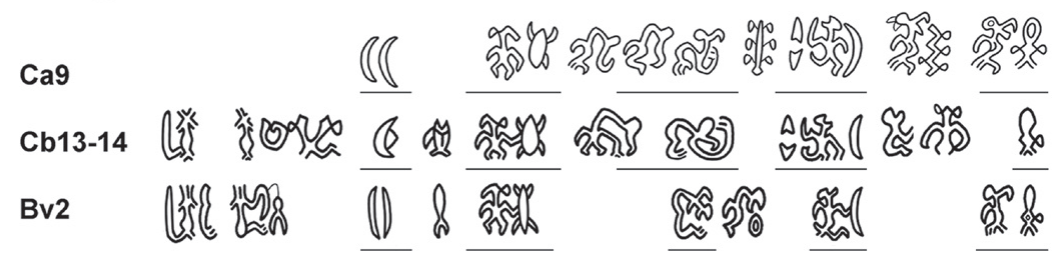

C

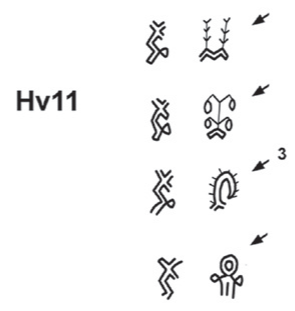

Hv11

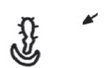

Bs

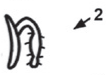

(1) $x^{1}$

(a)

D

Bv2

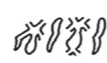

ॠ 80

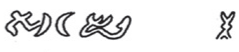

Cb13

को

पूत्र 18

(1) टूल है

Hv10

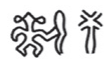

๘ DD

C(

\&

Pv11

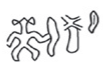

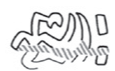

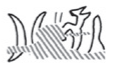

这

Figure 1. B. Ca09 x Cb14 x Bv02. C. Two lists of plants from the Great Santiago Tablet, Verso, Line 11. D. Bv02 x Cb13 x Hv10 x Pv11. B, C (after Paul Horley's drawings by his courtesy), $\mathrm{H}$ (after drawings by Bodo Spranz in Barthel 1958), P (drawing by the author). Arrows indicate inserted plants depicting signs, numbers by arrows indicate corresponding signs in the two lists of plants. 
period of the moon (1958: 242). Once this specific text portion is compared with known ethnographic records of the Easter Island lunar calendar, he suggested that a sign in the middle of the passage is the sign for the Full Moon depicting a "Man on the Moon" (1958: 245).

I question this interpretation for three reasons. First, there are no writing systems where signs function in such a "pictographic" manner: that is where a crescent is used for writing "one moon night", three crescents for writing "three moon nights" and five crescents for writing "five moon nights". Pictorial signs, that is to say, signs that depict humans, objects and actions abound in logosyllabic writing systems, and in many cases a depicted object or action is clearly connected with the meaning of word spelled by the sign, but they never depict phrases and sentences - in other words, they never depict situations, as do, for example, children's drawings and Orthodox icons. Second, the total number of crescents and their combining together are still unintelligible (for different opinions, see Guy 1990 and Horley 2011b). Third, as Konstantin Pozdniakov (2011) has astutely pointed out, Polynesia lunar calendars were very important for fishing, planting and measuring of time, but the social purposes of writing down a lunar calendar, in particular, in the middle of the long text on the Mamari Tablet are difficult to ascertain. While a solution to the last two objections might still be found in the future, in my opinion the first one is definitive and makes me profoundly sceptical about the widely accepted interpretation of the passage in question. Bearing this observation in mind, we can look for another possible interpretation of the passage.

\section{PASSAGE FROM THE MAMARI TABLET, LINES Ca6-9}

Let us have a closer look at the passage on the Mamari Tablet, Lines Ca6-9 (Fig. 1a). I present its structure in the following way.

There is a repetitive sequence of signs that defines the structure of the passage-Sequence $\alpha$. It is attested eight times $\alpha$ I-VIII. The passage begins with Sequence $\alpha \mathrm{I}$ as is suggested by four items of a list terminating in the sign ligature "Stick + Arm". The passage ends with Sequence $\alpha$ VIII where it suggests a combination of signs "Turtle - Sitting Creature - Sitting Creature" ( $\beta$ ) also attested in $\mathrm{Ca} 05$. This sign combination follows a sequence of signs (Fig. 1b) attested on the other tablets, if we assume that the omission of the "Upright Fish" sign on the Mamari Tablet is content-free or insignificant (for another proposal, see Horley 2011b: 22). It is easy to see that the examined structure looks circular starting and terminating with the same $\alpha$ sequence and thus it is incomplete. This fact makes the analysis problematic because implies a kind of distortion in the structure. The inserted signs, indicated with arrows on Fig. 1a, disturb the rigorous structure of the passage as well. 
There are isolated examples and multiple sequences of "Crescent" signs between Sequence $\alpha$ I and Sequence $\alpha$ VIII: A, AA, AAA?, AAAAA, AAAAAA. Five times different signs depicting plants appear to be inserted after "Crescent" signs ( $\alpha$ I, $\alpha$ III, $\alpha$ VI): "Sprout" "Two Leaved Vines Down", "Hanging Fruit", "Fern" and "Leaved Vine". Three of these signs also appear in two lists of signs depicting plants attested on the Great Santiago Tablet, Verso, Line 11 (Fig. 1c): one list is introduced with the "Twig" sign and another one with the "Crescent" sign. In my opinion, these lists represent the best evidence for the existence of word-signs in the kohau rongorongo script, as it is impossible to imagine such a structured sequence of signs depicting homogeneous objects occurring purely by chance. Two other signs or, perhaps better said, two ligatures appear inserted before Sequence $\alpha \mathrm{V}$. One of them may include a ligature version of the "Crescent" sign (see below). Another one represents the aforementioned "Man on the Moon". A "Bird" sign appears to be inserted after Sequence $\alpha$ VII.

The $\alpha$ sequence can be described in the following way: "Paunchy Bird + Crescent - Arm + Raised Wing + Sitting Man - Crescent - Long Beak - Star + Pendant + Fishing Line".

It should be noted that in fact the ligature "Paunchy Bird + Crescent" might be a composite sign, say "Paunchy Bird holding a Digging? Stick", because "Paunchy Bird" and "Crescent" in this sign combination are always written connected in the passage and significant variations in writing of either "Paunchy Bird" or "Crescent" are absent. Probably, a slightly different head of "Paunchy Bird" in Sequence $\alpha \mathrm{V}$ is not a ligature with "Bird", but just a scribal variant of the sign. The same seems to be true about "Left-Facing Long Beak" attested one time instead of "Right-Facing Long Beak" $(\alpha V)$, and "Uppercase Crescent" attested twice instead of "Full-sized Crescent" $(\alpha I V, \alpha V I)$. Because of this, I suggest nicknames for them without additional specification: "Paunchy Bird", "Long Beak" and "Crescent".

Another case is "Fishing Line with an Up Looking Fish", which is found in contrast distribution with "Fishing Line with a Down Looking Fish". Jacques Guy (1990: 140-41) was the first to notice that in the first half of the passage the sign is always written as "Up Looking Fish" $(\alpha \mathrm{I}-\alpha \mathrm{IV})$, while in the second half as "Down Looking Fish" ( $\alpha \mathrm{V}-\alpha \mathrm{VIII})$. According to the definitions above, it is an incomplete substitution. "Fishing Line with an Up Looking Fish" is a frequent sign, but it is never replaced with "Fishing Line with a Down Looking Fish" in parallel texts. The five examples of "Fishing Line with a Down Looking Fish" discussed are the only examples of the sign attested in the texts. Such a distribution is a strong indication that two signs have different but somehow related reading values. It is an example of incomplete substitution. Their contrasting iconic images and distribution 


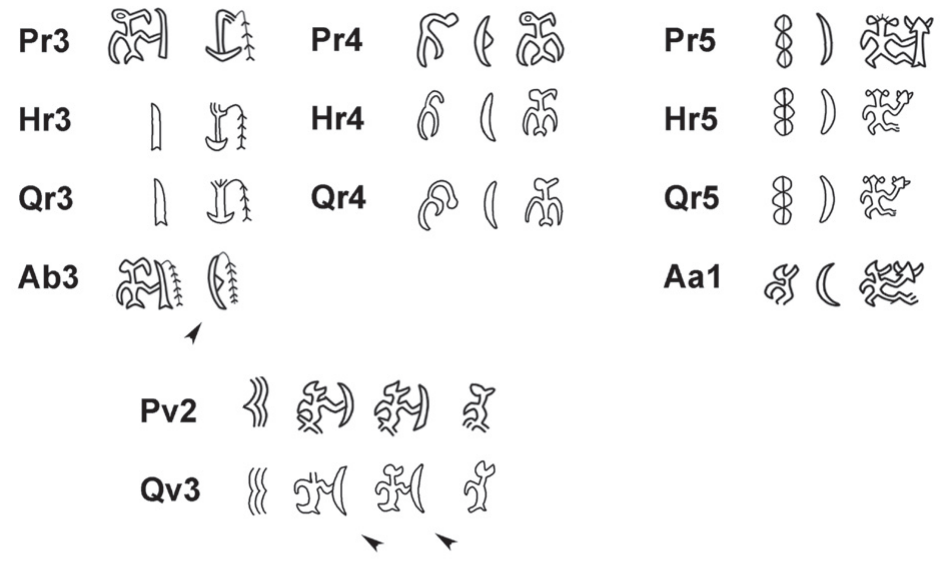

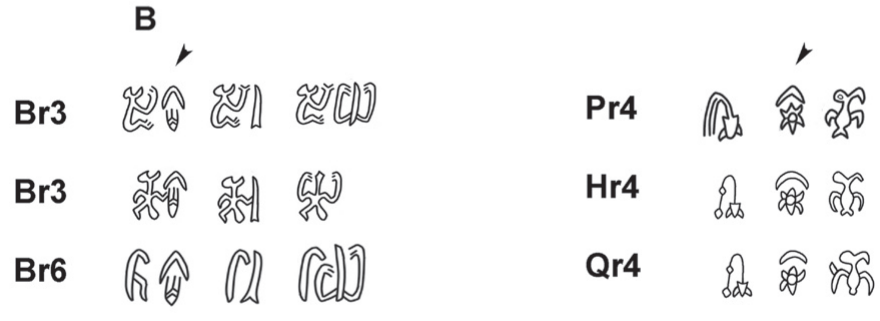

C

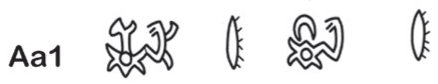

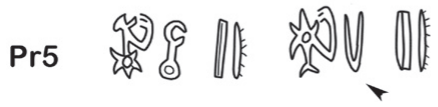

Figure 2. "Crescent" sign and its allographs.

A. Variants of the "Crescent" sign according to the parallel text attested on the Great St Petersburg Tablet, the Small St Petersburg Tablet and the Great Santiago Tablet. See also Fig. 1d, 5 and 8b. B. Examples of the "Above Arc" sign. C. Variants of the "Arc" sign. A, B and P (after Paul Horley's drawings by his courtesy), $\mathrm{H}$ and $\mathrm{Q}$ (after drawings by Roger Fischer 1997). Arrows indicate the signs under discussion. 
suggest that they are word-signs with opposite meanings like, for example, "above/below", "up/down", "ascend/descend", "put in/pull out", etc. It should be noted that the sign in Sequence $\alpha$ II is written on the very edge of the Tablet and because of this its reconstruction in the drawing is problematic (see Barthel 1958 and Fischer 1997). Gills, lateral line, number of fins and missing head are optional elements of various signs depicting fishes in the rongorongo script. Thus, these variations are probably insignificant.

An intricate substitution may be seen in Sequence $\alpha \mathrm{I}$, where the common sequence "Arm + Raised Wing + Sitting Man" is written as "Arm + Raised Wing + Sitting Man + Standing Man", or alternatively "Arm + Raised Wing + Standing Man". It is worthwhile to compare this sign combination with one attested in the intersection Bv02 x Cb13 x Hv10 x Pv11, where the "Arm" sign is always missing (Fig. 1d): "Raised Wing + Sitting Man", "Raised Wing + Long Beak + Sitting Man", "Raised Wing + Long Neck", where the "Long Beak" bird sign and the "Long Neck" man sign seem to be allographs, that is to say, two different signs that have the same value.

In analysing the structure of the passage on the Mamari Tablet, Lines Ca6-9, graphic variants of the Crescent sign warrant discussion. Paul Horley (2011b) and Pozdniakov (2011) both referred to Barthel who considered the "Left-Facing Crescent" and "Right-Facing Crescent" to be different signs. These graphic designs do have different number codes in Barthel's catalogue, though his text hints at the opposite point of view. Comparison of the three parallel texts (Fig. 2a) indicates that "Left-Facing Crescent", "Right-Facing Crescent" and "Up-Facing Crescent", and "Left-Facing Boat" and "Right-Facing Boat" are different ways of writing the same sign. By contrast, "Down-Facing Crescent" situated above other signs appears in only two contexts with three examples attested for each context and thus it should be considered as an independent sign (Fig. 2b). I propose the nickname "Above Arc" for the sign in question in order to distinguish it from different variants of the "Crescent" sign. Once "Above Arc" is replaced by "Below Arc" (Fig. 2c) in the well-known parallel sequence Aa01 x Pr05 (Guy 1985). ${ }^{3}$ Thus, "Above Arc" and "Below Arc" are two graphic variants of the same sign "Arc". When compared with the Mamari Tablet Line b13 (Fig. 1d) the sign appearing after Sequence $\alpha$ IV suggests that the "Crescent on Stem" is a rare ligature variant of the "Crescent" sign. "Right-Facing Crescent" is much more frequent than "Left-Facing Crescent" (159 examples versus 54 in the corpus according to Barthel's transcriptions), hinting at a different meaning. In fact, this divergence may be explained by the universal phenomenon of preference for right orientation in human cognition, to put it in a simpler way, by the fact that scribes are mostly right-handed. 
If "Left-Facing Crescent" and "Right-Facing Crescent" are variants of the same sign, a question arises that should be explicitly stated and possibly answered. Why are all the examples of the "Crescent" sign in the $\alpha$ sequence right-facing, while all the other examples of the "Crescent" sign in the passage are left-facing? Moreover, why are all the examples of the "Crescent" sign after "Paunchy Bird" connected with this sign as a ligature "Paunchy Bird + Crescent"? As a Mayanist, I am ready to say that this odd behaviour of the sign can be explained by graphic reasons, suggesting that while the scribe writes, he selects different variants and tries to accommodate them according to their shape. Taking a closer look, one should admit that there are no reasons for preferring "Left-Facing Crescent" for the $\alpha$ sequence, nor for writing it connected with "Paunchy Bird". There is another explanation. The AAAA and $\mathrm{ABAB}$ sign combinations of kohau rongorongo are supposed to spell reduplicated words with syllabic signs (Davletshin 2012, see also below). Sometimes, the AA and AB sign combinations which form part of these sequences as well as isolated AA combinations are written in such a way that two asymmetrical signs either look at each other or look in different directions resulting in mirroring images. Probably, AB combinations of $\mathrm{ABAB}$ sequences and A signs of AA combinations refer to single lexical units of Rapanui language.

Sadly, comparison of parallel texts shows that mirroring is not obligatory. Moreover, the same phenomenon can be seen in the ABCABC sequences of signs implying that the meaningful unit of mirroring is more than a lexical morpheme. I suggest that mirroring is used in the kohau rongorongo script for indicating syntactic words in the same way as hieroglyphic blocks are used in Maya writing (Davletshin 2003, 2005; on hieroglyphic blocks in Maya writing see Kettunen and Helmke 2010, Zender 1999). Reversed orientation of signs can be also used to show that two signs belong to two different meaningful units. In his recent paper Pozdniakov (2011) has arrived at a similar conclusion. Examples of both uses are seen in the adduced figures (for example Fig. 1c). Thus, in the passage on the Mamari Tablet "Crescent" signs of the $\alpha$ sequence are contrasted with "Crescent" signs forming successive sequences.

\section{SIGNS WITH UNEXPECTED COMBINATORIAL PROPERTIES: A CHALLENGE}

In a 2002 paper I argued that there are two different types of signs in kohau rongorongo texts according to their combinatorial properties. Signs of the first type form sequences of the kind ABAB, AAAA and AAA in combination with other signs of the same type. Signs of the second type are unable to enter into the mentioned combinations, even if frequently attested in the script. In all likelihood, these combinations correspond to the completely and partially reduplicated forms typical of Polynesian languages, as in the following 
Rapanui forms: tea-tea 'white', te-tea 'whitish', cf. tea 'early dawn', or te-tere 'to run away (plural subject)', cf. tere 'to run away' (singular), or mo-more 'to cut (plural object)', cf. more 'to cut (singular)', 'o- 'o 'otu 'to burn very much', 'o 'otu 'to burn', hatu-hatu 'to fold', cf. hatu 'to weave' (Du Feu 1996: 191). I have also argued that the ability of a sign to form sequences ABAB and AAAA indicates that the sign has a syllabic (phonetic) value, because such word combinations as, for example, "fish fish fish fish" do not make sense in any human language. Conformably, frequent signs unable to form these combinations are likely to be word-signs.

It is easy to see that combinations of the "Crescent" sign in kohau rongorongo texts offer a challenge for interpretation, as the sign is attested in the following combinations: A, AA, AAA, AAAA?, AAAAA, AAAAAA (Fig. 3). ${ }^{4}$ Neither a word, nor a syllable makes sense if repeated six times in succession. Let us imagine that "Crescent" is a syllabic sign with a $\mathrm{C}_{1} \mathrm{~V}_{1}$ reading value, where $\mathrm{C}$ stands for a consonant and $\mathrm{V}$ for a vowel. There is no such syllable in Rapanui which is attested as part of the following meaningful units $C_{1} V_{1}, C_{1} V_{1} C_{1} V_{1}, C_{1} V_{1} C_{1} V_{1} C_{1} V_{1}, C_{1} V_{1} C_{1} V_{1} C_{1} V_{1} C_{1} V_{1} C_{1} V_{l}$ and $C_{1} V_{1} C_{1} V_{1} C_{1} V_{1} C_{1} V_{1} C_{1} V_{1} C_{1} V_{1}$ (see Englert 1978). Moreover, such a syllable

A

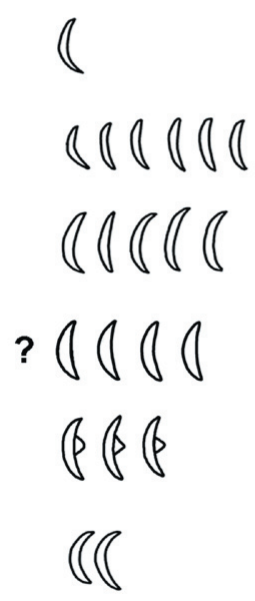

B

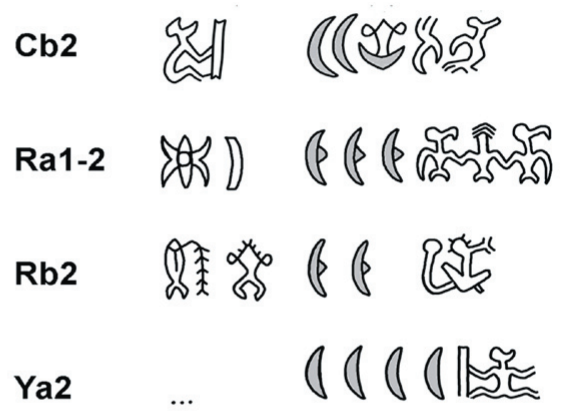

Figure 3. Successive sequences of the "Crescent" sign in kohau rongorongo texts. R, Y (after drawings by Roger Fischer 1997). 
AZTEC NUMERALS:

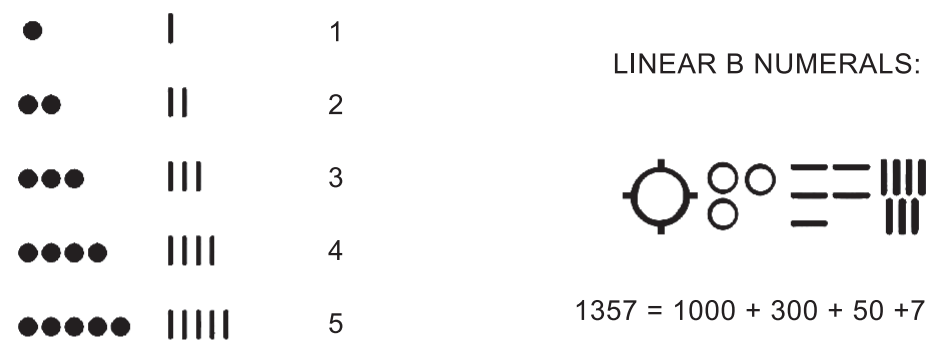

OLD PERSIAN NUMERALS:

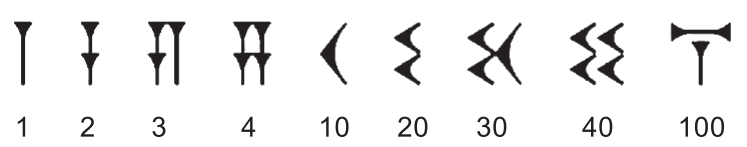

Figure 4. Numerals in various logosyllabic writing systems: do they follow the same pattern? (Images after Ancientscripts.com n.d.)

is unlikely to be found in any language anywhere in the world because of universal phonetic constraints on the morpheme structure.

A typological perspective on the world's writing systems offers a solution for this case. Probably, all known logosyllabic writing systems use dots, bars, semicircles and their combinations for writing numerals (e.g., Daniels and Bright 1996, Gregg 1989). I have chosen some revealing examples in order to illustrate this universal phenomenon (Fig. 4). Alphabetical and syllabic writings systems are different in this respect; many of them, for example Latin script, use non-iconic signs for writing numerals. Possibly this difference is owing to the lack of iconicity that is inherent to signs of alphabetical and purely syllabic scripts. Based on this observation, it is possible to suggest that "Crescent" and its combinations are word-signs for writing numbers in the script of Easter Island.

\section{ARGUMENTS IN FAVOUR OF THE INTERPRETATION OFFERED}

Various arguments support this proposal. First, different combinations of the crescent sign substitute for one another in two contexts: in the passage on the Mamari Tablet, Lines Ca6-9, where the combinations AAAAAA, AAAAA, AAA?, AA and A follow the sign group $\alpha$ (Fig. 1a), and in the intersection of 


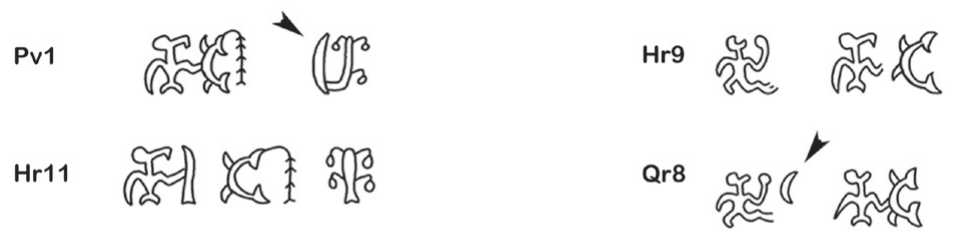

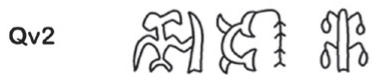

Figure 5. "Crescent" sign as a grammatical marker (after drawings by Roger Fischer 1997).

$\mathrm{Ca} 09 \times \mathrm{Cb} 14 \times \mathrm{Bv02}$, where AA and A are attested in the same context (Fig. 1b). Looking at the long parallel text recorded on three tablets (Kudrjavtsev 1949) on the Great St Petersburg Tablet "Crescent" is attested 19 times: 18 times it is substituted with different variants of the sign and once it is deleted (absent?) in the parallel texts. This simple analysis shows that the substitution between "Crescent" and its combinations is dependent on the context, that is to say, it is an example of incomplete substitution. And it is exactly what we expect to find for numerals, which possess similar, but not identical meanings.

The examples, where "Crescent" is substituted with zero, in other words with nothing (Fig. 5), is of particular interest for the suggested interpretation. Generally in Polynesian languages including Rapanui, the number 'one' $(e$ tahi) is used as indefinite article in the position before or after a noun (e.g., Du Feu 1996: 80). At the same time, various grammatical morphemes in the shape of zero are important in the grammar of the language and the so-called zero article is among them (e.g., Du Feu 1996: 136). It means that alternations with zero in parallel passages and paraphrases might be used for detection of grammatical markers in the kohau rongorongo script. Thus, it is possible to suggest that the sign is used as a grammatical marker and it is an expected property for the number ONE.

Another argument in support of the interpretation offered might be seen in the list of plants discussed above (Fig. 2c), where a "Crescent" sign is found in the front of different signs depicting "plants", introducing items of enumeration. A rough interpretation of the passage as "one such-andsuch plant, one such-and-such plant, etc." seems plausible, particularly if we recall the possible "indefinite article" reading of the numeral "one": "a such-and-such plant, a such-and-such plant, etc." Enumerations introduced by the numeral one are found in Rapanui traditional narratives. I would like 
to adduce an example from Manuscript E (69-69 [sic], Barthel 1974: 35960 ). The translation is mine; I make use of brackets for clarifying ambiguous and problematic places.

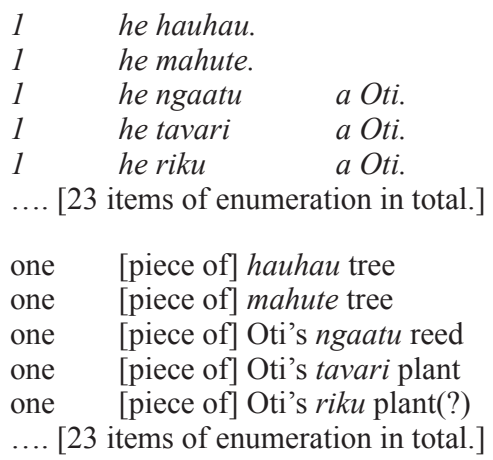

ARGUMENTS AGAINST THE INTERPRETATION OFFERED AND THEIR SOLUTION

From a methodological point of view I deem it important to intentionally look for and explicitly discuss evidence against the suggested interpretations, because this practice has the potential of dismissing suggestions and of finding new solutions and explanations. There are two examples in kohau rongorongo texts, where proposed numerals written with "Crescents" appear separated by inserted signs in parallel passages. One of them is mentioned above when discussing allographs of the "Crescent" sign (Fig. 1d), while the other is attested on the Keiti Tablet, Recto (Fig. 6). Of course, it is impossible to imagine "two" being written as "one-something-one" in a parallel text and "four" as "two-something-two".

It is useful to take a closer look at the Keiti Tablet, Recto (Fig. 6), a highly structured text that has received a lot of attention from scholars of the kohau rongorongo script (Horley 2010, Melka 2008, Pozdniakov 2011, Wieczorek 2011). For the purposes of this article I present its structure in the following way. First, there is a repetitive sequence of signs - Sequence $\gamma$ - presented in its two main versions: a complete one $\gamma^{\prime}$ and an abbreviated one $\gamma^{\prime \prime}$ (Fig. 6). The textual structure on the Keiti Tablet, Recto, can be described by means of the Sequence $\gamma$, the "Standing Man" sign and the "Adze" sign; the last one gives rise to many intricate ligatures and conflated glyphs in the text. The text starts with a $\gamma^{\prime \prime}$ sequence $(\gamma \mathrm{I})$ followed by a varying fragment of text $\delta \mathrm{I}$, then nine $\gamma^{\prime}$ sequences $(\gamma \mathrm{II}-\mathrm{X})$ accompanied by a varying fragment of following text $(\delta \mathrm{II}-\mathrm{X})$. There is a sign combination "Standing Man $+($ Arm $)+$ 


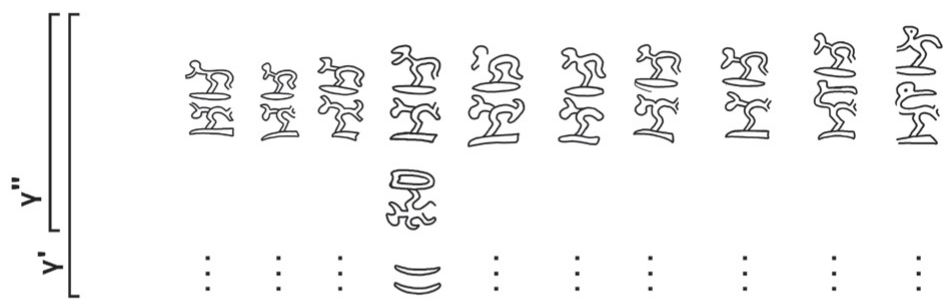

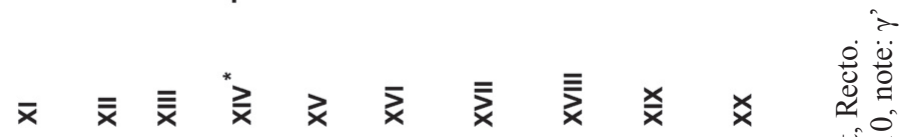

홀ㅎำ

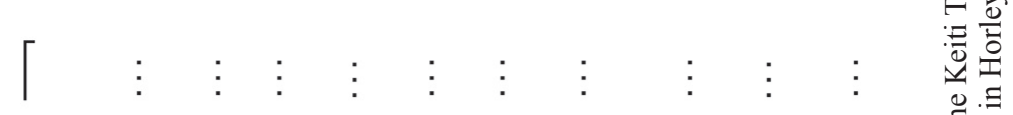

$\stackrel{Ð}{\Xi}$ |

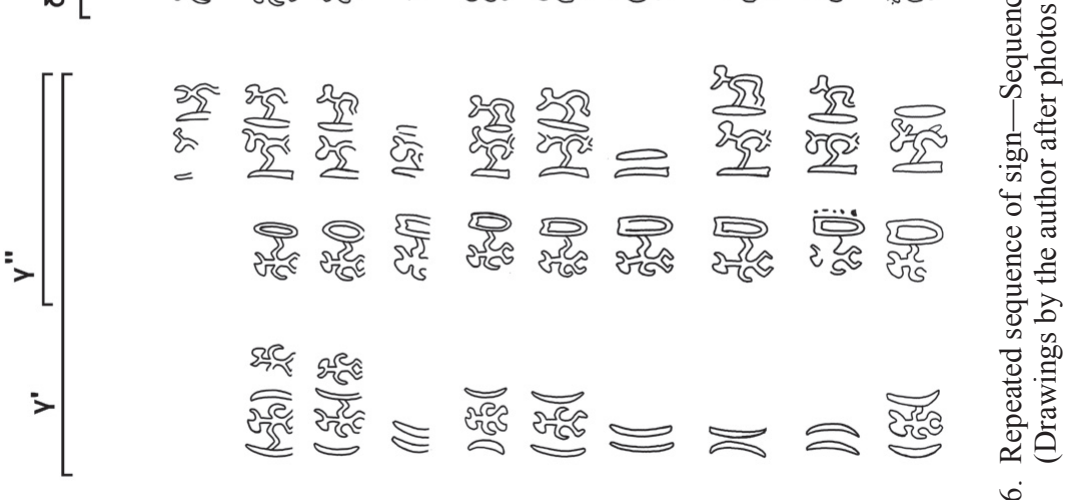

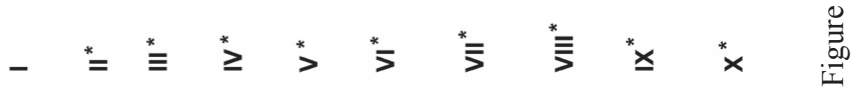


Adze" after Sequences $\gamma$ II-IX and the varying text between Sequences $\gamma \mathrm{I}$ and $\gamma \mathrm{X}$ (i.e., $\delta \mathrm{I}-\mathrm{IX})$ represent lists specified by the "Adze" sign, in $\delta \mathrm{V}$ and $\delta \mathrm{VI}$ lists specified by the "Standing Man + (Arm) + Adze" combination, where brackets indicate that the sign in question can be omitted. It should be noted that Sequences $\delta I-I X$ are of more or less equal length. This highly structured fragment of text is followed by a varying text with ten $\gamma$ sequences ( $\gamma$ XI-XX), and only one of them is not $\gamma^{\prime \prime}$, but $\gamma^{\prime}(\gamma \mathrm{XIV})$. Various structured sequences of signs, as for example lists ABACADADAEAFAG, ABCDABCD, ABAB, $\mathrm{ABA}, \mathrm{AA}$, appear in the text between $\gamma \mathrm{X}$ and $\gamma \mathrm{XX}$. The last $\gamma$ sequence is followed by a long sequence of signs ending on the obverse of the Keiti Tablet (Er09-Ev01); it is also attested on other tablets (Ca01 x Hr01 x Pr01 x Na05 x Ra05-06 x Sa07). This sequence of signs was first retrieved by Pozdniakov (1996: Fig. 7c). It appears in the beginning of three texts (Cr01, $\mathrm{Hr} 01, \mathrm{Pr} 01)$. I believe that the cited sign-sequence indicates the beginning of a new text and the end of the old one. The sequence in question can be called "introductory sign sequence" and functionally it can be defined as an opening sentence of kohau rongorongo texts. The text begins with a $\gamma$ " sequence and ends with a $\gamma^{\prime \prime}$ sequence. Thus, the structure of the text is circular and incomplete, implying some kind of distortion in the structure, because it starts and ends with the same phrase.

The structure of the longer version of the $\gamma$ sequence, that is to say, $\gamma^{\prime}$, can be described in the following way: "Crescent - (Standing Man) - Crescent - (Standing Man) - Man holding a Shield - Knife with a Nestling - Sitting Man holding a Tablet", where brackets indicate that the sign in question can be omitted. Correspondingly, the shorter version, that is to say, $\gamma$ ", is "Knife with a Nestling - Sitting Man holding a Tablet".

The last three signs of the sequence are problematic. Two stand-alone "Shield" signs are attested though in different contexts (Br05, Ca12). Moreover, these two examples of "Shield" show a notch not at the top, but at the bottom, though both variants are found under the same number (28) in Barthel's catalogue. Because of this, it might be better to consider "Man holding a Shield" as a ligature of two signs "Standing Man" and "Shield". I refrain from analysing "Knife with a Nestling" as a combination of two independent signs "Knife" and "Nestling", because "Nestling" attested in other contexts does not show this wide range of variation in writing, though it can be attributed to the scribal hand that carved the Keiti Tablet. "Knife with a Nestling" is written as "Knife" ( $\gamma$ VII) once, and three times "Sitting Man holding a Tablet" is written as "Tablet" $(\gamma \mathrm{IV}, \gamma \mathrm{VII}, \gamma \mathrm{X})$. In these cases if "Knife with a Nestling" and "Sitting Man holding a Tablet" are not ligatures, but independent signs, "Knife" and "Tablet" are abbreviated or, in other words, incomplete forms of composite signs. A similar graphic phenomenon 
A

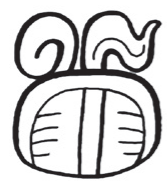

Q॥
B
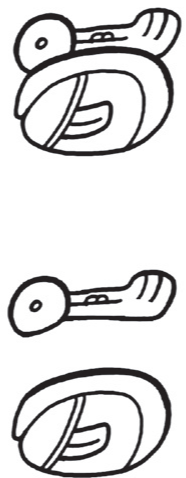

C

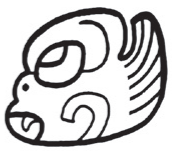

MPIT

Figure 7. Complete and incomplete forms of signs in Maya writing.

A. K'ahk' FIRE. B. TE?TREE, WOOD. C. ka.

(Drawings by the author.)

is known in the Maya hieroglyphic script (Fig. 7) (see for example, Kettunen and Helmke 2010, Stuart 1995: 37, Zender 1999). If "Knife with a Nestling" and "Sitting Man holding a Tablet" are ligatures, syllabic signs "Nestling" and "Sitting Man" should be used as phonetic complements for word-signs "Knife" and "Tablet". However, "Knife" appears in combinations ABAB indicating that it has a syllabic (phonetic) value and consequently it cannot be complemented with other phonetic signs. The "Tablet" sign is different from the "Tuber" sign, though both of them are under the same number (22) in Barthel's catalogue. The only difference between the two is that "Tuber" has "roots" added. "Tablet" and "Tuber" are never substitutes for each other. While "Tuber" is probably a phonetic sign (for AAA see Hv10 x Pv11), "Tablet" is a word-sign, because it is not attested in AAAA and AAA combinations and only once is it found as part of a sequence $\mathrm{ABAB}(\mathrm{Br} 07)$. To the $\mathrm{ABAB}$ sequence in question (Br07) there corresponds one example of $\mathrm{AB}$ combination ( $\mathrm{Gv} 08)$, so we may deal with a stylistic repetition here. Stylistic repetitions of this kind are frequently found in Rapanui traditional narratives.

Returning to the two "Crescent" signs in the beginning of the $\gamma$ ' sequence. A "Standing Man" optionally appears after the first "Crescent" sign or after the second one, or after both (Fig. 8a). This behaviour when a sign is optionally found in the position after another one in substitutions is typical for syllabic signs used as phonetic complements. Another example of the sequence "Crescent - Standing Man" being replaced with "Crescent" can be 


\section{A

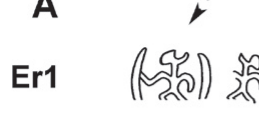 \\ Er1 Vחת \\ Er2

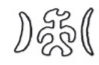

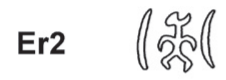 \\ Er4

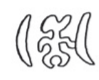 \\ C}

B
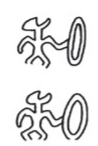

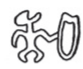

$\operatorname{Pr} 9$

Hr8

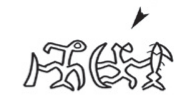

เ资 造

\section{Da3}
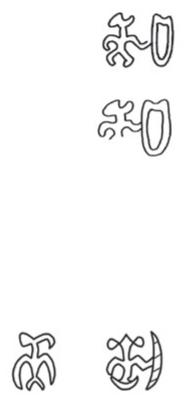

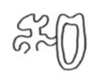
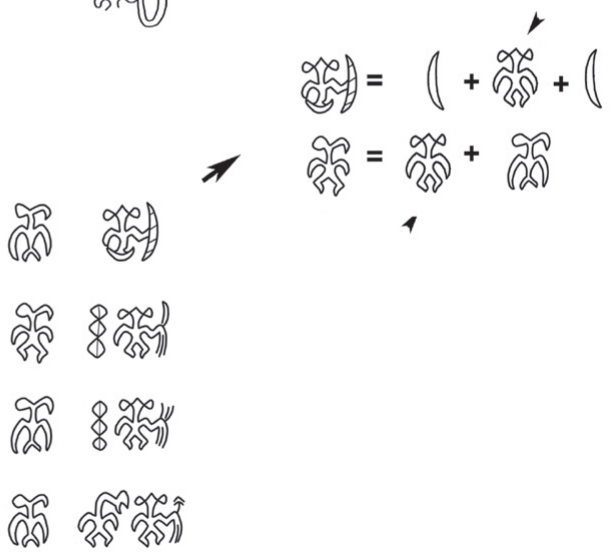

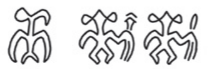

Figure 8. Phonetic complements for the "Crescent" sign?

A. Keiti Tablet, Recto. B. Intersection of the Great St Petersburg Tablet, Great Santiago Tablet and Small St Petersburg Tablet. C. Échancrée Tablet Line a3. Text D, H and P (after Paul Horley's drawings by his courtesy). Text E (drawings by the author after photographs from Horley 2010). Arrows indicate probable phonetic complements.

found if we look at the long parallel text at Pr08 x Hr08 x Qr08 (Fig. 8b) and we admit that "Man with Its Right Leg Stretched-out" is one of the ligature versions of the sign "Standing Man", but not the "Running Man" sign. A similar sequence of signs "Crescent + Standing Man + Crescent - Standing Man + Bird" is found on the Énchancrée Tablet (Fig. 8c). If the sign for 


\section{A Er3 lD

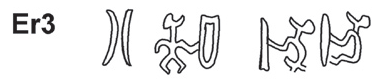

B

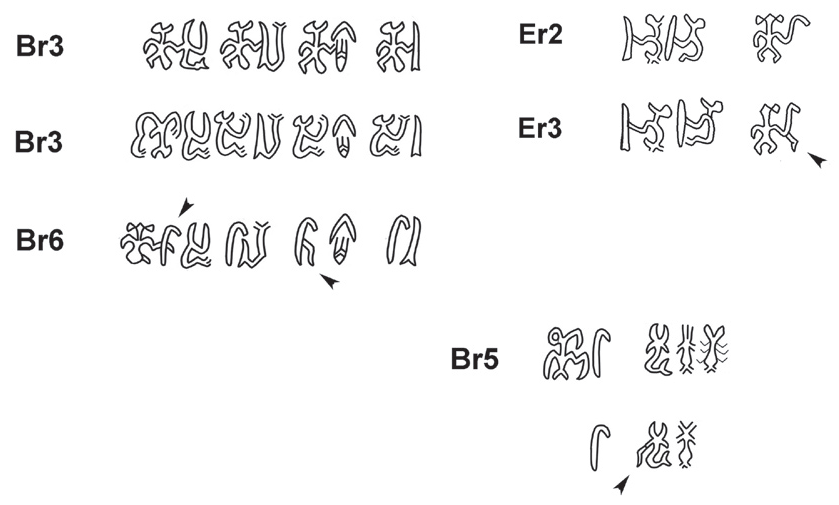

Figure 9. Probable phonetic complements on the Keiti Tablet, Recto.

A. "Man holding a Shield" written as "Man holding a Shield + Leaved Vine?". B. "Adze + Suspended Poker". E (drawings by the author after photographs in Horley 2010). B (after Paul Horley's drawings by his courtesy). Arrows indicate probable phonetic complements.

number "one" is used on the Keiti Tablet for writing a homophonic word, it is possible to understand why the sign is frequently complemented there: it might be used in order to clarify the phonetic reading of the sign and thus to avoid confusion between a "Two Crescents" sign for "two" and an identically looking sign combination of "Crescent - Crescent" intended to be read "one" and "one". Possibly, mirroring of the "Crescent" signs is used for the same purpose here. No phonetic complements have been suggested hitherto by kohau rongorongo scholars, but I will argue that even on the Keiti Tablet, Recto, it is possible to find two more indicative examples of this universal feature of logosyllabic writing systems. One of them is a "Leaved Vine" sign that appears after a "Man holding a Shield" in Sequence $\gamma$ IX (Fig. 9a). 
Although the sign in question is indicated by Steven R. Fischer in his drawing of the tablet (1997), it does not appear in Barthel's (1958) and Horley's (2010) drawings, but it can be seen on the published photo (Horley 2010: Fig. 4). The "Leaved Vine" sign is attested in its atypical version, possibly the result of being squeezed owing to the lack of space, so its precise identification remains problematic; it also resembles a "Threaded Berries" sign. Another example of substitution includes a sign undocumented in Barthel's catalogue and transcriptions - "Suspended Poker". It appears twice in combination with the "Adze" sign on the Keiti Tablet (Fig. 9b). The same sign is frequently attested in the same position on the Aruku Kurenga Tablet. The "Suspended Poker" sign is optionally used after the "Adze" sign in strict substitutions (Br03 x Br03 x Br06, Br05 x Br05 on Fig. 9b), which makes this case a clear example of phonetic complementation.

The word for 'one' in Rapanui language is tahi. If the above suggestion is correct, the reading of the first word in the Sequence $\gamma^{\prime}$ is tahi-tahi and the "Standing Man" sign is a syllabic sign either with the value hi or $\mathbf{i}^{5}{ }^{5} \mathrm{In}$ fact, the sign seems to be a syllabic one, because it is attested in the ABAB sign combinations. Rapanui tahi-tahi means 'raspar con cuchillo/to scrape with knife' (Englert 1978). The word is securely reconstructed after the proto-Polynesian *tasi 'to scrape, to shave' (Biggs and Clark n.d.). Such a word makes sense in the contexts of the kohau rongorongo tablets if we understand it as a term for 'manufacturing of tablets' or 'carving of signs'. Moreover, the "Adze" sign frequently attested on the Keiti Tablet, Recto seems to support this interpretation. "Adze" is a word-sign as its combinatory properties, probable phonetic complements and lists marked with "Adze" signs suggest. Comparison with the "Adze" rock-art motif of Easter Island (Lee 1992: 42) implies that the sign depicts an adze or a similar tool that might be used to cut and square wood for tablets. Taking into account imagery of the signs in the $\alpha$ sequence and the standard Rapanui syntax, it is possible to suggest the following interpretation of the $\gamma^{\prime}$ sequence: [a] tayata ma 'ori ("Man" holding a "Shield") tahitahi cuts (Crescent-Crescent), [a] kohau ("Sitting Man" holding a "Tablet") gets fluted/carved motu? ("Knife" with a "Nestling") with the adze ("Standing Man" + "Arm" + "Adze"). Tayata $m a$ 'ori is a native term referring to experts of the kohau rongorongo script (Englert 1978: 191); the term motu means 'cortar, grabar (letras o figuras en piedra o madera)/to cut, incise (characters in stone or wood)', see also kohau motu = kohau royoroyo 'madera con inscripciones/inscribed wood', kohau 'palo, tableta/stick, tablet' (see Englert 1978). Thus the interpretation of the $\gamma$ " sequence is: kohau ("Sitting Man" holding a "Tablet") motu ("Knife" with a "Nestling"), giving 'tablets get fluted/carved'. This interpretation is too bold to be accepted, but is worthy of mentioning because it gives an idea how matters can syntactically work in Rapanui language. 
The same kind of reasoning might be applied for the above mentioned case where "four" in parallel texts is written as "two-something-two" (Fig. 1c). However, I am not satisfied with this interpretation. First, possible meanings of the word do not seem to be promising. Rua is the word for 'two' in Rapanui, but rua also means (i) 'vomitar/to vomit' and (ii) 'fosa, hueco/hole' (Englert 1978). Words like "vomiting, to vomit a lot" and "holed, perforated" would not be expected to appear on the tablets. However the Nuclear Polynesian * rua 'to accompany, be coupled with' and Māori ruarua 'several' (Biggs and Clark n.d.) might fit better. Second, the inserted signs, which may be used as phonetic complements, are abstruse. In order for the suggestion to hold, we should consider the "Screaming Creature" sign (Bv2) and the "Notched Stick?"/"Falling Squares?" sign (Pv11) to be phonetic and allographs, that is to say, to have the same syllabic reading value. Unfortunately, both signs are unique and moreover both examples of the "Falling Squares?" sign on the St Petersburg Tablet are nearly obliterated and hinder their comparison with other signs. It is still possible that both signs represent rare allographs of an unknown common sign that has the syllabic value $\mathbf{a}$, and this one is frequently attested in the script. Alternatively, we can suggest that the second "Falling Squares?" sign, which is heavily weathered, is another sign having nothing to do with "Falling Squares?". Then, "Screaming Creature" and "Falling Squares?" are not allographs, and "Falling Squares?" can be a ru syllabic sign used as a phonetic complement for RUA TWO. Yet another possible solution is to suggest that the sequence "two + (something) + two + (something)" is one of the stylistic repetitions frequently found in the kohau rongorongo texts and "something" corresponds to postverbal grammatical markers that can be omitted and can substitute for one another in parallel texts.

To sum up, it has been useful to discuss two cases which seem to contradict the interpretation I have offered. One of them (Fig. 6) happens to be a clear case of phonetic complementation. Its detailed examination allows me to offer a promising tentative reading tahi-tahi 'cut (wood)/ manufacture (tablets)'. Thus, this counterexample supports the interpretation. Three plausible explanations are suggested for the second case (Fig. 1c). It is impossible to decide between them or dismiss them owing to the lack of combinatory data available, but it means that it cannot be considered as a counterexample to the interpretation offered.

\section{IMPLICATIONS: NUMERALS OF HIGHER ORDERS}

The proposed identification of the signs for ONE, TWO, THREE, FOUR?, FIVE and SIX implies how the signs for SEVEN, EIGHT and NINE should look. We can assume that they represent multiplied "Crescent" signs, because, first, numerals of Rapanui and other Polynesian languages represent counting systems which have ten as their base (Lemaitre 1985) and, second, it is common 
for logosyllabic writing systems to use special signs for numbers of different orders (Daniels and Bright 1996). The only exception I know of is the Modern Chinese Script, where a corresponding number of "bars" is used for writing three first numbers only and numerals from four on are written with unrelated signs, but we can consider the case negligible to a preliminary approximation.

The proposal automatically raises a question about the numerals of higher orders that should be found in association with the first nine numerals. It is tempting to suggest that the ligature of three signs attested before number TWO in the intersection Bv02 x Cb13 x Hv10 x Pv11 and before number ONE in the so-called calendric passage on the Mamari Tablet represent a numeral of a higher order TEN? phonetically spelled. If this is the case, the sign or a ligature of signs attested at the beginning of the $\alpha$ sequence on the Mamari Tablet and followed by number ONE can be a numeral of an even higher order HUNDRED? It might give an attractive solution of TWENTY TWO for the complicated issue related to the passage $\mathrm{Bv} 02 \times \mathrm{Cb} 13 \times \mathrm{Hv} 10$ $\mathrm{x}$ Pv11 discussed above. Moreover, the probable reading of the passage on the St Petersburg Tablet Pv11 "Crescent - Falling Squares? - Two Crescents - Falling Squares?" favours such an interpretation. Unfortunately, I would reject this suggestion, because in Rapanui and other Polynesian languages the numeral qualifying a counting base of higher order always precedes the base, as for example, e-tahi te piere e-rima te rau e-há te kauatu ma-toru mamoe '1543 sheep' [1 x 1000, 5 x 100, 4 x 10 plus 3 sheep] (Englert 1978: 59). Another suggestive numeral of higher order might be the "Turtle" sign on the Mamari Tablet Ca09. In his article of 1962 Barthel mentions that his Rapanui informant in discussing the Mamari Tablet indicated that the word honu 'turtle' also meant 'thirty' in the old times. This interpretation is attractive to some extent, because the number of Crescent signs 28 ? in the passage on the Mamari, with the exception of those in the $\alpha$ sequences, is close to the resulting meaning of "thirty" as if the scribe were summing up the total. Two lacking "Crescents" appear two signs later, after the Turtle sign, implying something like "thirty in total if we add two". This suggestion also makes the structure of the passage more regular, and therefore more understandable, as every $\alpha$ sequence of the Mamari Tablet is followed by a numeral or by a series of presumed numerals. Nevertheless, I hesitate to accept this suggestion for two reasons. As far as I can judge from Barthel's article (1962: 3), his questions to the informant were too coercive and the received responses too ambiguous, and no one else has recorded the word honu for 'thirty' on Easter Island. He also did not explain that the expression tini honu 'when somebody five times continuously wins in a card game', can be literally translated as 'full, i.e., complete, multitude' (see proto-Polynesian *fonu in Biggs and Clark n.d.). In addition, numerals based on names for animals and objects are not attested 
elsewhere in Polynesia (Lemaître 1985, Bender and Beller 2007, Gregg 1989). It is also tempting to consider the "Boat" version of the "Crescent" sign to be a number of a higher order TEN?, but the analysis of parallel texts offered above implies that it is just a variant of "Crescent".

The interpretation of numerals set forth in this article implies a tally, a list of the contents or a register as an explanation for the so-called calendric passage attested on the Mamari, Lines Ca6-9. Let us imagine a possible interpretation of the passage: "an official? in a certain district? gathered tribute - one measure, such-a-such plant - one measure, such-a-such plant $(\alpha \mathrm{I})$; an official? in a certain district? gathered tribute - six measures $(\alpha \mathrm{II})$; etc. ... the tally? is complete ( $\beta$ )". It is easy to see that inserted signs lacking "Crescents" receive a plausible(?) interpretation as items unspecified by numerals. It should be stressed that numerals are always used as modifiers for counted objects in languages and scripts. One can assume that a calendric interpretation of the passage is also possible in a similar way. However, in such a case it is unclear where the sign for "Moon/Night" is to be found. The signs depicting plants that appear to be inserted between the "Crescent" signs in the passage also make a calendric interpretation problematic.

Surprisingly, the combination of signs "Turtle - Sitting Creature - Sitting Creature" attested in $\mathrm{Ca} 05$ also appears after a list marked with a plant sign Ca04-05 as if it was a concluding part of the list. I am dissatisfied with the assumption that the sign depicting 'turtle' honu (Englert 1978) is used to write a word honu 'full', because word-signs are infrequently used to spell homonymous words with different meanings, though they do so in all known logosyllabic writing systems. Neither I am content with the fact that the widespread word in Polynesian languages *fonu 'full, be full' is not attested in Rapanui dictionaries (however, see tini honu in Barthel 1963: 2).

It should also be noted that enumerations and, in particular, lists with numerals is one of the stylistic devices frequently found in traditional folklore texts of Polynesia and, in particular, in Rapanui traditional historical narratives (see, for example, Manuscript E: 1, 2, 24, 38-42, 62-64, 65-66, 67-72, 78-80 in Barthel 1974). Interestingly, some of enumerations in the Manuscript $\mathrm{E}$ are counted lists of plants. I would like to present an example from the text; the translation is mine (Manuscript E: 71, Barthel 1974: 361; also see Fedorova 1988: 69).

he ki hokoou a Hotu.kia Teke.e hakarite te tangata.ana too koe ki runga ki te miro.peira tokoa te manu vae ehä.te kekepu.tokoa.te moa tokoa.

he oho. a Teke.anake ko toona titiro.he too mai i te manu vae ehā.ko te tamaroa ko te tamahine.erima te kauatu te manu eva eha.

$50 \quad$ manu vae ehā.

he too mai anake te huru o te manu ko te tamaa(-) 
roa ko te tamahahine tokoa
100 kekepu.
500 he moa
5

Hotu says to Teke again: "Make equal parts of the humans (men and women?), when you are going to take them on the boat, as well as of quadrupeds (sheep? pigs?), also kekepu (turtles? pigs? seals?), also chickens!"

Teke goes with his followers. They take quadrupeds (sheep?), males and females (rams and ewes?), 50 quadrupeds (sheep?).

50 quadrupeds (sheep?).

they take every kind of animals, males and also females

100 kekepu (turtles? pigs? seals?).

$500 \quad$ chickens

5 five bottles of flies.

A word of caution should be voiced concerning every reading value proposed in this article; promising as each seems to be, they are only tentative until confirmed by cross-readings. I regard the proposed reading values well grounded, but a reading value can be considered established only in cases when it is shown to be working in different contexts. Until that happens, any readings should be considered provisional. We need to collect as much contextually grounded content interpretations and phonetic readings based on these content interpretations as possible; then we will be able to check probable phonetic values in independent contexts.

$$
* * *
$$

The typological approach to the study of the kohau rongorongo script and the method of sign substitution applied in this article have resulted in new observations and promising interpretatations. The most interesting proposals are the identification of basic numerals and final phonetic complements in the script. The hypothesis of numerals has allowed me to explain anomalous repetitions of identical signs; the hypothesis of phonetic complements has allowed me to explain anomalous behaviour of two signs in many examples of substitution in different contexts. Numerals and phonetic complements allow me to offer a provisional reading tahi-tahi 'cut/manufacture (tablets for writing?)'.

It has been shown that the widely accepted interpretation of the passage on the Mamari Tablet, Lines Ca6-9 as a record of the lunar calendar is problematic from various points of view. I believe that an inventory, a content-list and a register, used as a rhetorical device in the text, is a more promising content interpretation. Such an interpretation finds its structural parallels in traditional Rapanui historical narratives. 


\section{APPENDIX: LIST OF THE SIGNS DISCUSSED AND THEIR NUMBERS ACCORDING TO THOMAS BARTHEL'S CATALOGUE (1958):}

Above Arc, variant of Arc: 43

Adze: 63

Arc: 27,43

Arm: 6

Below Arc, variant of Arc: $27 \mathrm{~b}$

Bird: 600

Boat, variant of Crescent: 40b, $41 \mathrm{~b}$

Crescent: 40, 41, 42

Crescent on Stem: ?

Falling Squares: 16

Fern: 59

Fishing Line: 711

Hanging Fruit: 74

Knife: 4

Knife with a Nestling: 4+430?

Leaved Vine: 3

Left-Facing Boat, variant of Crescent: 41b

Left-Facing Crescent, variant of Crescent: 41a

Long Beak: 670, see Long Neck

Long Neck, variant of Long Beak: 460

Man holding a Shield: $300+28$

Nestling: 430?

Notched Stick: 11

Paunchy Bird: 390
Pendant: 78

Raised Wing: ?

Right-Facing Boat, variant of Crescent: 40b

Right-Facing Crescent, variant of

Crescent: 40a

Running Man: 320

Screaming Creature: ? cf. 445

Shield: 28

Sitting Creature: 382

Sitting Man: 380

Sitting Man holding a Tablet: $20 \mathrm{a}+380$

Sprout: 10a

Standing Man: 200, 300

Star: 8

Stick: 1a

Suspended Poker: ?

Tablet: 22a-b

Threaded Berries: 37

Tuber: $22 \mathrm{c}-\mathrm{d}$

Turtle: 280

Twig: 68

Two Leaved Vines Down: 30a

Up-Facing Crescent, variant of Crescent: 42 Upright Fish: 700

Uppercase of Crescent, variant of Crescent: ?

\section{ACKNOWLEDGEMENTS}

I would like to thank my friends and colleagues who have helped me through discussions and in providing me with materials: Artem Kozmin, Dmitri Beliaev, Evgenia Korovina, Martyn Harris, Paul Horley, Paulus Kieviet, Rafal Wieczorek, Scott Nicolay, Tomi Melka and Vladimir Belikov. I am very much obliged to Paul Horley for his kind permission to use his unpublished drawings. I am also grateful to the anonymous reviewer for valuable comments. Many thanks go to the curators Pavel Belkov and Tatiana Sokolova (Peter the Great Museum of Anthropology and Ethnography, St Petersburg) and to Jill Hasell (British Museum, London) for giving me the opportunity to work with the original artefacts. This study is based on results obtained during my six month stay at the Department of "Anthropology of the Americas", Bonn University, supported by an Immanuel Kant Scholarship offered by the German Academic Exchange Service (2009-2010). 


\section{NOTES}

1. There is no consensus on how to count kohau rongorongo signs. The given number is obtained by counting writing units separated by blank spaces according to the transcriptions published by Barthel in 1958. Many such units represent ligatures of single signs, but this is the only impartial way to evaluate the size of the corpus available, at least while our understanding of the kohau rongorongo graphics is so incomplete. Documentation has been improved since 1958, so the total length of the corpus is a little bit bigger. For example, a new text, the Paris Snuffbox, has been found (Barthel 1963: 373, Fischer 1997, Pozdniakov 1996). The total corpus according to Barthel (1958: 15-33) is 14,312-14,337 signs and according to Steven R. Fischer (1997: 409-507) 14,787 signs. The reader should add up numbers given by the authors for individual texts.

2. It is either an erratum or a misunderstanding about the form of the waxing moon by Barthel.

3. I would like to thank Evgenia Korovina (pers. comm. 2011) who reminded me about this substitution at the right moment.

4. The suggestion was originally presented in a paper: "Kohau rongorongo script of Easter Island as a logosyllabic writing system" read at 11th International Conference on Austronesian Linguistics, Aussois, France (22-26 June 2009).

5. This suggestion implies that the sign for ONE can possess related but different reading values as TAHI and E-TAHI. The conjecture, doubtful as it seems to be, agrees with a phenomenon widely attested in many writing systems, e.g., English " 1 " is read as both 'one' and 'first'.

\section{REFERENCES}

Ancientscripts.com, n.d. Ancient Scripts: A Compendium of World-wide Writing Systems from Prehistory to Today. http://www.ancientscripts.com/.

Barthel, Thomas S., 1958. Grundlagen zur Entzifferung der Osterinselschrift. Abhandlungen aus dem Gebiet der Auslandskunde 64, Reihe B: Völkerkunde, Kulturgeschichte und Sprachen Band 36. Hamburg: Cram, de Gruyter.

1962. Zählweise und Zahlenglaube der Osterinsulaner. Abhandlungen und Berichte des Staatlichen Museums fur Völkerkunde (Dresden), 21: 1-22.

1963. Rongorongo-Studien (Forschungen und Fortschritte bei der weiteren Entzifferung der Osterinselschrift). Anthropos, 58: 372-436.

-1974. Das achte Land: Die Entdeckung und Besiedlung der Osterinsel. München: Klaus Renner.

Beckwith, Martha, 1940. Hawaiian Mythology. New Haven: Yale University Press. Bender, Andrea and Sieghard Beller, 2007. Numeral classifiers in specific counting systems: Cultural context, linguistic principles, and cognitive implications. In D.S. McNamara and J.G. Trafton (eds), Proceedings of the 29th Annual Conference of the Cognitive Science Society. New York: Erlbaum, pp. 821-26. 
Berthin, Gordon and Michael Berthin, 2006. Astronomical utility and poetic metaphor in the Rongorongo lunar calendar. Applied Semiotics/Sémiotique appliquée, 18: 85-99.

Biggs, Bruce and Ross Clark, n.d. Polynesian Lexicon Project Online. http://pollex. org.nz/.

Butinov, Nikolai A., and Yuri V. Knorozov [Бутинов Н.А., Кнорозов Ю.В.], 1956. Предварительное сообщение о письме острова Пасхи. Советская этнография 4: 77-91 [in Russian, also appeared as Butinov and Knorozov 1957].

1957. Preliminary report on the study of the written language of Easter Island. Journal of the Polynesian Society, 66: 5-17.

Caplice, Richard, 2002. Introduction to Akkadian. 4th Edition. Rome: Biblical Institute Press.

Daniels, Peter T. and William Bright (eds), 1996. The World's Writing Systems. New York-Oxford: Oxford University Press.

Davletshin, Albert, 2002. From Kohau Rongorongo tablets to Rapanui social organization: From Rapanui social organization to Kohau Rongorongo script. In D. Beliaev, S.A. Frantsuzov (eds), Abstracts of the Second International Conference Hierarchy and Power in the History of Civilizations (St.-Petersburg, July 4-7, 2002). Moscow, p. 249.

2003. Glyph blocks in the Maya script: Towards a new definition. In Abstract booklet. The 16th International Conference on Historical Linguistics, Copenhagen, Denmark, August 11-15, 2003. New-York, p. 207. [See 2005 below.]

2012. Name in the Kohau Rongorongo script (Easter Island). Journal de la Société des Océanistes, 134 (1): 71-85.

[Davletshin, Albert] [Давлетшин А.И.], 2005. Размышления о словесном знаке: к типологии словесно-слоговых систем письма. В “Эдубба вечна и постоянна: Материаль конференции, посвященной 90-летию со дня рождения Игоря Михайловича Дьяконова”. Санкт-Петербург, С. 49-63. [Publication in Russian expanded from 2003 above.]

Du Feu, Veronica M., 1996. Rapanui. Descriptive Grammars Series. London-New York: Routledge.

Englert, Sebastian, 1978. Idioma rapanui: Gramática y diccionario del antiguo idioma de la Isla de Pascua. Santiago de Chile: Universidad de Chile.

Fedorova, Irina К. [Фёдорова И.К.], 1982. Исследование рапануйских текстов. В Ю.В. Кнорозов (ред.), Забытые системы письма: Остров Пасхи, Великое Ляо, Индия (материаль к дешифровке). Москва: Наука, С. 23-98 [in Russian].

1988. Мифы и легенды острова Пасхи. Ленинград: Наука [in Russian]. -1997. О характере текста на жезле с острова Пасхи. В Е.В. Ревуненкова, Н.А. Бутинов (ред.), Этнография, история, культура стран южньх морей: Маклаевские чтения 1995-1997 г2. С.-Петербург, С. 64-69 [in Russian].

Fischer, Stephen R., 1997. Rongorongo, the Easter Island Script: History, Traditions, Texts. Oxford Studies in Anthropological Linguistics 14. Oxford and New York: Oxford University Press. 
Fox, James A. and John S. Justeson, 1984. Conventions for the transliteration of Mayan hieroglyphs. In J.S. Justeson and L.R. Campbell (eds), Phoneticism in Mayan Hieroglyphic Writing. Institute for Mesoamerican Studies Monograph 9. Albany: SUNY, pp. 363-66.

Gelb, Ignace J., 1963. A Study of Writing: A Discussion of the General Principles Governing the Use and Evolution of Writing. 2nd Edition. Chicago-London: University of Chicago Press.

Gregg, Graham (ed.), 1989. Numbers through the Ages. London: Macmillan \& The Open University.

Grube, Nikolai, 2010. Preposed phonetic complements in Maya hieroglyphic writing. In E.B. Carlin and S. van de Kerke (eds), Linguistics and Archaeology in the Americas: The Historization of Language and Society. Leiden-Boston: Brill, pp. 27-44.

Guy, Jacques B.M., 1982. Fused glyphs in the Easter Island script. Journal of the Polynesian Society, 91: 445-47.

1985. On a fragment of the "Tahua" Tablet. Journal of the Polynesian Society, 94: 367-88.

-1990. The lunar calendar of Tablet Mamari. Journal de la Société des Océanistes, 91 (2): 135-49.

Harris, Martyn, 2010. Corpus Linguistics as a Method for the Decipherment of Rongorongo. Unpublished MA thesis in Applied Linguistics, Birkbeck University, London.

Harrison, J. Park, 1874. The hieroglyphics of Easter Island. Journal of the Royal Anthropological Institute of Great Britain and Ireland, 3: 370-82.

Heyerdahl, Thor, 1975. Art of Easter Island. New York: Doubleday.

Horley, Paul, 2005. Allographic variations and statistical analysis of the Rongorongo script. Rapa Nui Journal, 19 (2): 107-16.

-2007. Structural analysis of Rongorongo inscriptions. Rapa Nui Journal, 21 (1): 25-32.

2009. Rongorongo script: Carving techniques and scribal corrections. Journal de la Société des Océanistes, 129: 249-61.

2010. Rongorongo Tablet Keiti. Rapa Nui Journal, 24 (1): 45-56. 2011a. Palaeographic analysis of the Santiago staff. Rapa Nui Journal, 25 (1): 31-43.

2011b. Lunar calendar in Rongorongo texts and rock art of Easter Island. Journal de la Société des Océanistes, 132: 17-38.

Houston, Stephen D., David Stuart and Karl A. Taube, 1989. Folk classification of Classic Maya pottery. American Anthropologist (n.s.), 91 (3): 720-26.

Jaussen, Florentin Étienne, 1893. L'île de Pâques: Historique, écriture et répertoire des signes des tablettes ou bois d'hibiscus intelligents. Edited by Ildfonse Alazard. Paris: Leroux.

Kettunen, Harri and Christophe Helmke, 2010. Introduction to Maya Hieroglyphs. 11th Edition. XVI Maya Conference, Madrid 2010. Madrid: Wayeb/S.E.E.M.

Knorozov, Yuri V. [Кнорозов Ю.В.], 1952. Древняя письменность центральной Америки. Советская этнография, 3: 100-18. 
1982. Неизвестные тексты. В Ю.В. Кнорозов (ред.), Забытые системы письма: Остров Пасхи, Великое Ляо, Индия (материаль по дешифровке). Москва: Наука, С. 3-10 [in Russian].

Kondratov, Alexander М. [Кондратов А.М.], 1969. Статистические методы дешифровки некоторых письмён Востока и Средиземноморья. Дис. канд. ист. наук, Институт Народов Востока АНСССР [in Russian].

1976. Письменность острова Пасхи. В И.М. Дьяконов (ред.), Тайньь древних письмён: проблемы дешифровки. Москва: Наука, С. 531-38, 559 [in Russian].

Krupa, Viktor, 1971. 'Moon' in the writing of Easter Island. Oceanic Linguistics, 10: 1-10. Kudrjavtsev, Boris G. [Кудрявцев Б.Г.], 1949. Письменность острова Пасхи. Сборник музея антропологии и этнографии, 11: 175-221 [in Russian].

Lee, Georgia, 1992. Rock Art of Easter Island. Los Angeles: UCLA Institute of Archaeology.

Lemaître, Yves, 1985. Les systèmes de numération en Polynésie orientale. Journal de la Société des Océanistes, 80: 3-13.

Lounsbury, Floyd, 1984. Glyphic substitutions: Homophonic and synonymic. In J.S. Justeson and L.R. Campbell (eds), Phoneticism in Mayan Hieroglyphic Writing. Institute for Mesoamerican Studies Monograph 9. Albany: SUNY, pp. 167-84.

Mathews, Peter, 1979. The glyphs on the ear ornaments from tomb A-1/1. In D. Pendergast, Excavations at Altun Ha, Belize, 1964-1970, Volume 1. Toronto: Royal Ontario Museum, pp. 79-80.

Melka, Tomi S., 2008. Structural observations regarding Rongorongo Tablet "Keiti". Cryptologia, 32: 155-79.

2009a. Some considerations about the Kohau Rongorongo script in the light of a statistical analysis of the Santiago Staff. Cryptologia 33 (1): 24-73.

- 2009b. The corpus problem in the Rongorongo studies. Glottotheory: International Journal of Linguistics, 2 (1): 111-36.

Métraux, Alfred, 1940. Ethnology of Easter Island. Bernice P. Bishop Museum Bulletin 160. Honolulu.

Olderrogge, Dmitrij А. [Ольдерогге Д.А.], 1949. Параллельные тексты таблиц острова Пасхи "Кохау ронгоронго". Сборник музея антропологии и этнографии, 11: 222-36 [in Russian].

Orliac, Catherine, and Michel Orliac, 1995. Bois sculptés de l'Île de Pâques. Marseille: Éditions Parenthèses / Éditions Louise Leiris.

-2008. Trésors de l'île de Pâques / Treasures of Easter Island. Paris: Éditions D / Éditions Louise Leiris.

Payne, Annick, 2010. Hieroglyphic Luwian: An Introduction with Original Texts. 2nd Edition. Wiesbaden: Harrassowitz Verlag.

Piotrowski, A., 1925. Deux tablettes avec les marques gravées de l'île de Pâques de la collection de N. N. Mikloukho-Maklay. Revue d'Ethnographie et des Traditions Populaires, 6 (23-24): 425-31.

Pozdniakov, Igor and Konstantin Pozdniakov, 2007. Rapanui writing and the Rapanui language: preliminary results of a statistical analysis. Forum for Anthropology and Culture, 3: 3-36. 
Pozdniakov, Konstantin, 1996. Les bases du déchiffrement de l'écriture de l'île de Pâques. Journal de la Société des Océanistes, 103: 289-303.

2011. Tablet Keiti and calendar-like structures in Rapanui script. Journal de la Société des Océanistes, 132: 39-74.

Ramírez, José Miguel and Carlos Huber, 2000. Easter Island: Rapa Nui, A Land of Rocky Dreams. Santiago: Alvimpress Impresores.

Ross, Alan S.C., 1940. The Easter Island Tablet Atua-mata-riri. Journal of the Polynesian Society, 49: 556-63.

Stuart, David, 1987. Ten Phonetic Syllables. Research Reports on Ancient Maya Writing 14. Washington D.C.

-1995. A Study of Maya Inscriptions. Unpublished PhD dissertation, Nashville: Vanderbuilt University, Department of Anthropology.

Van Hoorebeeck, Albert. 1979. La vérité sur l'île de Pâques. Le Havre: Pierrette d'Antoine.

Wieczorek, Rafal M., 2011. Astronomical content in Rongorongo Tablet Keiti. Journal de la Société des Océanistes, 132: 5-16.

Zender, Marc, 1999. Diacritical Marks and Underspelling in the Classic Maya Script: Implications for Decipherment. Unpublished MA thesis, University of Calgary.

\begin{abstract}
Typological considerations and combinatory properties of the "Crescent" sign suggest that "Crescent" and its multiplied combinations represent numerals in the kohau rongorongo script of Easter Island. Probable phonetic complements for the "Crescent" sign identified by means of the substitution method reinforce this interpretation. As a result, some phonetic readings and an alternative content interpretation of the socalled calendric passage on the Mamari Tablet are proposed.
\end{abstract}

Keywords: kohau rongorongo script of Easter Island, logosyllabic writing systems, numerical signs, phonetic complements, substitution method 